\title{
WAKAF UANG UNTUK PENGEMBANGAN OPERASIONAL KEGIATAN MASJID
}

\author{
Nurul Huda, Hulmansyah, Zulihar \\ Program Magister Manajemen, Universitas YARSI \\ Email : nurul.huda@yarsi.ac.id
}

\begin{abstract}
ABSTRAK
Rendahnya dana wakaf ini disebabkan karena edukasi tentang wakaf uang ini masih dirasakan kurang. Masyarakat di Indonesia secara umum lebih mengenal istilah wakaf adalah dengan harta benda tidak bergerak seperti masjid atau tanah dan peruntukan wakaf banyak dipergunakan untuk keperluan ibadah, perkuburan, dan pendidikan. Pelatihan ini bertujuan untuk lebih mensosialisasikan wakaf uang guna membantu pengembangan operasional kegiatan Masjid. Metode yang digunakan berupa pelatihan dan pendampingan bagi pengurus Masjid. Hasil pengujian Pre dan post test menyimpilkan pelatihan berpengaruh signifikan terhadap pengetahuan peserta terkait wakaf uang.
\end{abstract}

Kata kunci : Wakaf uang, pengurus masjid, pre dan post test

\begin{abstract}
This low waqf fund was due to the lack of education about money waqf. The general public in Indonesia is more familiar with the term waqf with immovable property such as mosques or land and the allocation of waqf is mostly used for the purposes of worship, burial, and education. This training aims to better socialize money waqf to help develop operational activities of mosques. The method is used in the form of training and mentoring for mosque administrators. The results of the Pre and post-test training test have a significant effect on participants' knowledge regarding money waqf.
\end{abstract}

Keywords : Money waqf, mosque management, pre and post test

\section{PENDAHULUAN}

Waqf atau wakaf secara bahasa berarti berhenti, menahan atau diam. Dari sudut pandang syariah, wakaf sering diartikan sebagai asset yang dialokasikan untuk kemanfaatan ummat di mana substansi pokoknya ditahan, sementara manfaatnya boleh dinikmati untuk kepentingan umum.
Secara umum tidak terdapat ayat al-Qur'an yang menerangkan konsep wakaf secara konkrit tekstual.Wakaf termasuk infaq fi sabilillah, maka dasar yang digunakan para ulama dalam menerangkan konsep wakaf ini didasarkan pada keumuman ayat-ayat al-Qur'an yang menjelaskan tentang infaq fi sabilillah. Di antara ayat-ayat 
tersebut antara lain: QS : Al-Baqarah : 267

267. Hai orang-orang yang beriman, nafkahkanlah (di jalan allah) sebagian dari hasil usahamu yang baikbaik dan sebagian dari apa yang Kami keluarkan dari bumi untuk kamu. Dan janganlah kamu memilih yang burukburuk lalu kamu menafkahkan daripadanya, padahal kamu sendiri tidak mau mengambilnya melainkan dengan memincingkan mata terhadapnya. Dan ketahuilah, bahwa Allah Maha Kaya lagi Maha Terpuji

Selain itu Hadits yang diriwayatkan oleh Muslim dari Ibnu Umar “"Bahwa Umar bin al Khattab r.a. memperoleh tanah di Khaibar, lalu ia datang kepada Nabi saw. untuk meminta petunjuk mengenai tanah tersebut. Ia berkata, "Wahai Rasulullah saya memperoleh tanah di Khaibar yang belum pernah saya peroleh harta yang lebih baik bagiku melebihi tanah tersebut; apa perintah engkau kepadaku mengenainya? Nabi saw.menjawab: "Jika mau, kamu tahan pokoknya dan kamu sedekahkan hasilnya. Ibnu Umar berkata "Maka, Umar menyedekahkan tanah tersebut, dengan mensyaratkan bahwa tanah itu tidak dijual, tidak dihibahkan, dan tidak diwariskan.Ia menyedekahkan hasilnya kepada fuqara', kerabat, riqab, sabilillah, ibnu sabil, dan tamu. Tidak berdosa atas orang yang mengelolanya untuk memakan dari hasil itu secara ma'ruf dan memberi makan kepada orang lain tanpa menjadikannya sebagai harta hak milik.

Ada dua pendapat yang berkembang di kalangan ahli yurisprudensi Islam (fuqaha') tentang siapa yang pertama kali melaksanakan syariat wakaf. Menurut sebagian pendapat ulama mengatakan bahwa yang pertama kali melaksanakan wakaf adalah Rasulullah saw. yaitu wakaf tanah milik Nabi sawuntuk dibangun masjid. Sebagian ulama menyatakan bahwa yang pertama kali melaksanakan syari'at wakaf adalah Umar bin Khatab (Hasan, 2003). Pendapat ini berdasarkan hadits yang diriwayatkan Ibnu Umar ra, sebagaimana telah dikemukakan di atas.

Wakaf tunai (cash waqf) pertama kali dipakai pada masa Utsman di Mesir, diakhir abad ke-16 (1555-1823 M)(Cizakca, 2004). Pada era Utsmani di Mesir, berkembang pemakaian fikih Hanafi dalam menjalankan aktivitas binis dan sosialnya. Imam Muhammad asy-Syaibani menjelaskan bahwa sekalipun tidak ada dukungan hadis 
yangkuat, penggunaan harta bergerak sebagai wakaf dibolehkan, jika memang hal itu sudah menjadi kebiasaan umum pada daerah tertentu.Bahkan bagi Imam Muhammad Al-Sarakhsi, kebiasaan umum tidak selalu menjadi persyaratan dalam penggunaan harta bergerak sebagai harta wakaf. Bahkan menurut Crecelius, Dia menyatakan: "No Islamic State was more energetic in its production of statistical records, moresystematic in its record keeping, and more assiduous in preserving these records thanthe Ottoman Empire (Arif, 2010).

Menurut UU No. 41 Tahun 2004 tentang Wakaf, wakaf uang adalah perbuatan hukum Wakif untuk memisahkan dan atau menyerahkan sebagian harta benda miliknya yang berupa uang untuk dimanfaatkan selamanya atau untuk jangka waktu tertentu sesuai dengan kepentingannya guna keperluan ibadah dan atau kesejahteraan umum menurut syariah. Selanjutnya, wakaf uang dalam definisi Departemen Agama adalah wakaf yang dilakukan seseorang, kelompok orang, dan lembaga atau badan hukum dalam bentuk uang. Dengan demikian, wakaf uang merupakan salah satu bentuk wakaf yang diserahkan oleh seorang wakif kepada nadzir dalam bentuk uang kontan.

Masyarakat di Indonesia secara umum lebih mengenal istilah wakaf adalah dengan harta benda tidak bergerak seperti masjid atau tanah dan peruntukan wakaf banyak dipergunakan untuk keperluan ibadah, perkuburan, dan pendidikan. Hal ini diperkuat dengan hasil penelitian Pusat Bahasa dan Budaya (PBB) UIN Syarif Hidayatullah Jakarta dalam Dahlan (2014) menunjukkan, bahwa harta wakaf lebih banyak bersifat diam (77\%) daripada yang menghasilkan atau produktif (23\%). Temuan lain menunjukkan, pemanfaatan terbesar harta wakaf adalah masjid (79\%) daripada peruntukan lainnya, dan lebih banyak berada di wilayah pedesaan $(59 \%)$ daripada perkotaan $(41 \%)$. Hal ini menunjukkan bahwa tanah wakaf yang cukup luas itu belum memberikan manfaat produktif, melainkan sebagian besar masih dipergunakan untuk keperluan konsumtif.

Pemanfaatan wakaf untuk keperluan lain masih terkendali dengan terbatasnya pemahaman hukum pengelolaan wakaf para pengelola wakaf. Sedangkan di masa sekarang terjadi perluasan pengelolaan dan 
pengembangan harta wakaf ke arah peningkatan kesejahteraan sosial ekonomi masyarakat berdasarkan UU No. 41 Tahun 2004 tentang wakaf.

Wakaf uang yang sudah dicanangkan Presiden Susilo Bambang Yudhoyono pada bulan Januari 2010, hingga tahun 2017 baru terkumpul Rp 199 Milyar, tentu angka ini masih sangat rendah. Guna meningkatkan besaran wakaf uang yang dihimpun maka perlu adanya edukasi untuk lebih meningkatkan pemahaman tentang wakaf uang itu sendiri.

Secara umum pengelolaan Masjid kita masih memprihatinkan. Apa kiranya solusi yang bisa dicoba untuk ditawarkan dalam mengaktualisasikan fungsi dan peran Masjid di era modern. Hal ini selayaknya perlu kita pikirkan bersama agar Masjid dapat menjadi sentra aktivitas kehidupan umat kembali sebagaimana telah ditauladankan oleh Rasulullah SAW bersama para sahabatnya.

Kita perlu melakukan pemberdayaan Masjid dahulu sebelum mengoptimalkan fungsi dan perannya. Dalam pemberdayaan ini kita bisa menggunakan metode Continuous Consolidation and Improvement for Mosque (CCIM) atau Penguatan dan
Perbaikan Berkelanjutan untuk Masjid. CCIM adalah Metode Pemberdayaan Masjid dengan menata kembali organisasi Ta'mir Masjid melalui pemanfaatan segenap potensi yang dimiliki diikuti dengan perbaikan yang dilakukan secara terus menerus.

Wakaf uang bisa menjadi salah satu solusi untuk model pemberdayaan Masjid dan pendanaan operasional Masjid. Sumber dana Masjid selama ini masih menempuh cara konvensional yaitu sumbangan utama dari dari jamaah," Jamaah shalat dan pengajian rutin di masjid menyumbang lewat kotak amal. Sudah seharusnya pengelolalaan Masjid memanfaatkan instrumen wakaf uang yang saat ini masih terus dikembangkan

\section{Perumusan Masalah}

Dua permasalahan utama yang dimunculkan yaitu (1) masih rendahnya penghimpunan wakaf uang yang salah satunya disebabkan kurang pemahaman tentang wakaf uang itu sendiri dan adanya anggapan bahwa wakaf hanya untuk harta tidak bergerak seperti tanah, kuburan dan lembaga pendidikan (2) Sumber pendanaan masjid masih dominan bersumber dari infaq jamaah melalui kotak amal, sehingga terkadang 
tidak bisa menutpi biaya operasional masjid

\section{KHALAYAK SASARAN}

Sasaran kegiatan ini merupakan Pengurus atau Pengelola Masjid serta Remaja Masjid yang berada disekitar Kecamatan Cempaka Putih dan Masjid di daerah lain dengan Undangan Khusus.

\section{METODE KEGIATAN}

Kegiatan PKM ini bertujuan untuk membantu memberikan solusi atas dua persoalan yang sudah dikemukakan di atas yaitu : pengembangan wakaf uang dan persoalan pendanaan operasional Masjid. Metode yang dilakukan dengan menggunakan dua pendekatan yaitu pelatihan dan pendampingan.

\section{Tim P2M}

\section{Pendampingan}

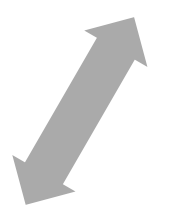

\section{Pelatihan}

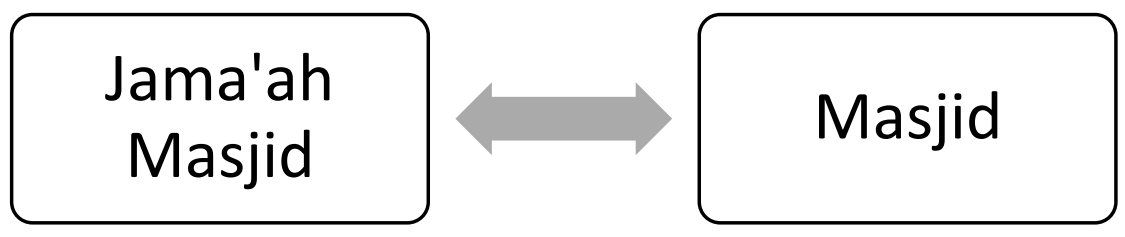

Gambar 1 Skema Kegiatan

\section{HASIL DAN PEMBAHASAN}

\section{Deskripsi Peserta Kegiatan}

Kegiatan pelatihan dilakukan pada tanggal 27 Maret 2019 dengan Target peserta 20 Pengurus Masjid (10 Masjid), realisasinya 34 orang yang hadir. Jumlah data yang bisa diolah sebanyak 22 dari 34 peserta yang absen, berikut deskripsi Peserta Kegiatan berdasarkan :

1. Jenis Kelamin, Peserta yang hadir berdasarkan jenis kelamin dominan laki-laki sebanyak 19 orang dan sisanya wanita 3 Orang yang berasal 
dari Masjid Al-Khobir dan IBS bawah ini.

seperti terlihat dalam gambar di

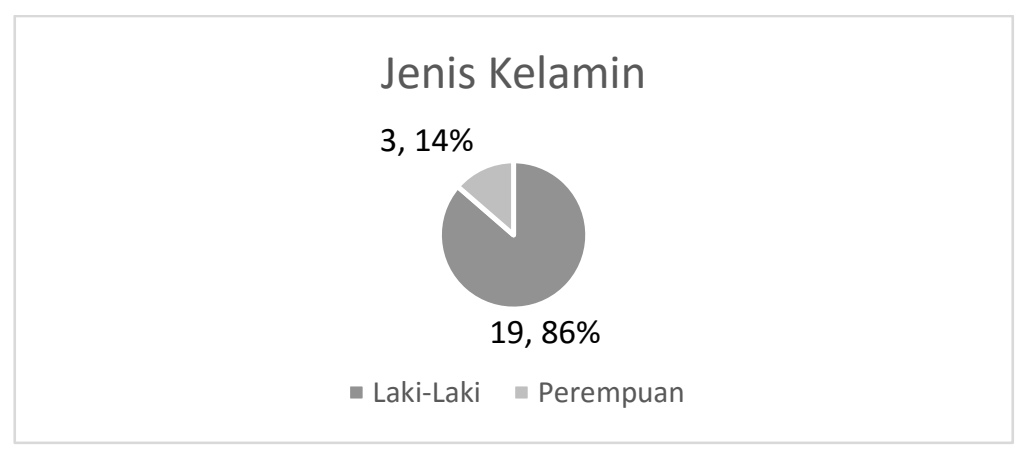

Gambar 2 Peserta berdasarkan Jenis Kelamin

Sumber : Kuesioner, data diolah

2. Usia, peserta yang hadir dari segi usia sangat variatif, peserta dengan presentase terbesar yaitu yang berusia $35-50$ Tahun sebanyak 8 $(36 \%)$, selanjutnya $>50$ Tahun sebanyak 7 (32 \%) . Hal ini memberikan indikasi masih kurangnya tenaga Remaja atau Dewasa untuk mengelola Masjid. Berikut lebih lanjut sebaran Peserta berdasarkan usia.

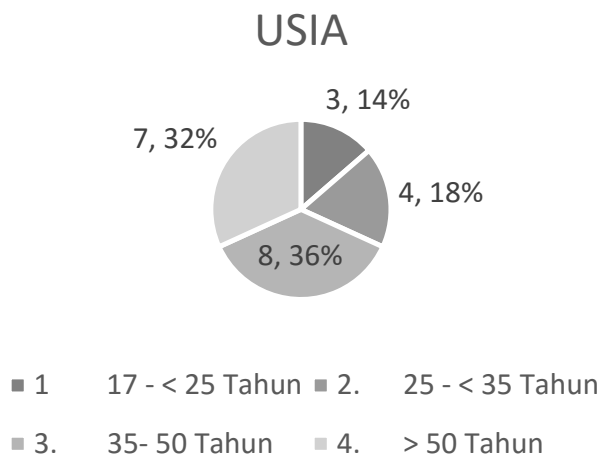

Gambar 3 Peserta berdasarkan Usia

Sumber : Kuesioner, data diolah 
3. Pendidikan, peserta kegiatan pascasarjana sebanyak 2 (9\%), dominan berpendidkan sarjana Berikut lebih lanjut sebaran Peserta sebanyak 13 orang (59\%) dan berdasarkan pendidikan.

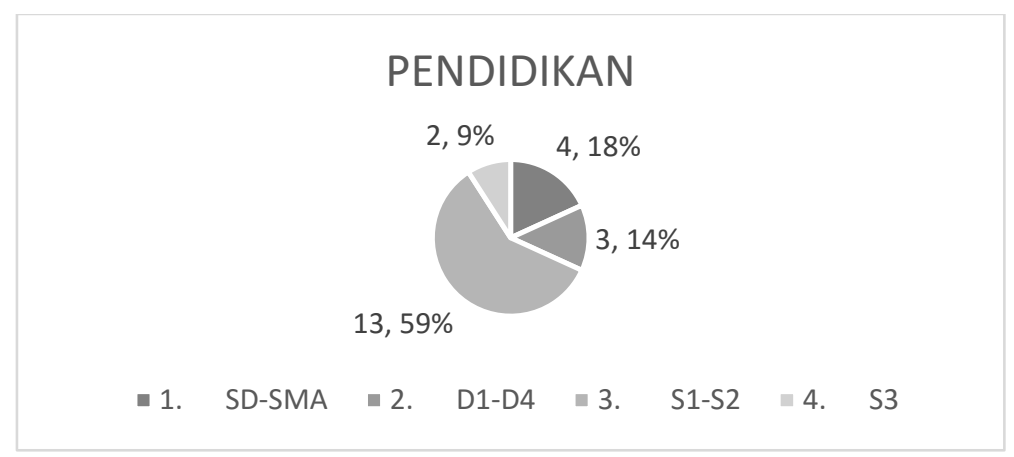

Gambar 4 Peserta berdasarkan Pendidikan

Sumber : Kuesioner, data diolah

4. Pekerjaan, peserta kegiatan memiliki pekerjaan yang bervariasi yaitu pegawai swasta 6 Orang $(27 \%)$, dosen 5 orang (23\%), yang terbanyak lainnya sebanyak 7 Orang (32\%).
Lainnya ini juga bervariasi dari Guru, Mahasiswa dan pensiunan. Berikut distribusi peserta berdasarkan pekerjaan

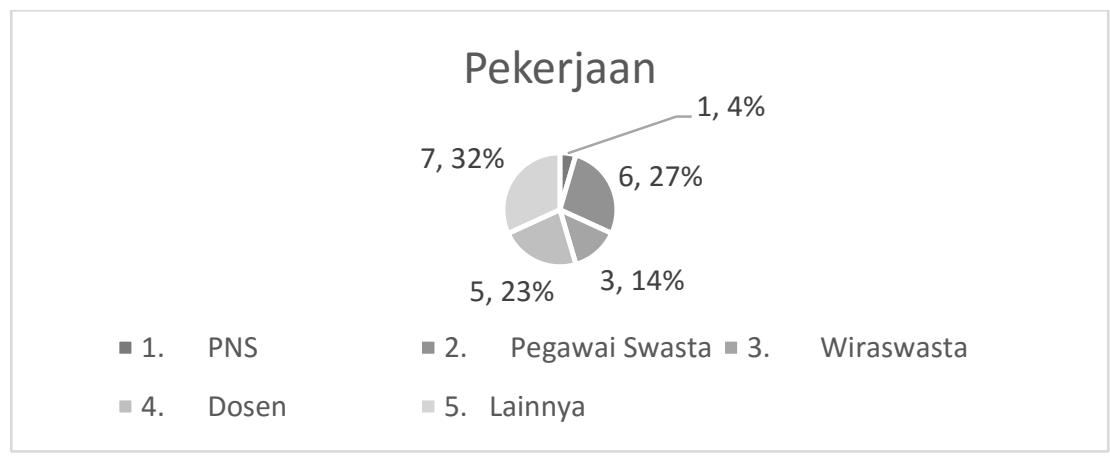

Gambar 5 Peserta berdasarkan Jenis Pekerjaan

Sumber : Kuesioner, data diolah 
5. Peran Peserta di Masjid, dominan peserta yang mengikuti kegiatan merupaka pengurus Masjid $68 \%$ dan pernah jadi pengurus 1 orang (5\%).

Berikut lebih lanjut sebaran Peserta berdasarkan peran peserta di Masjid

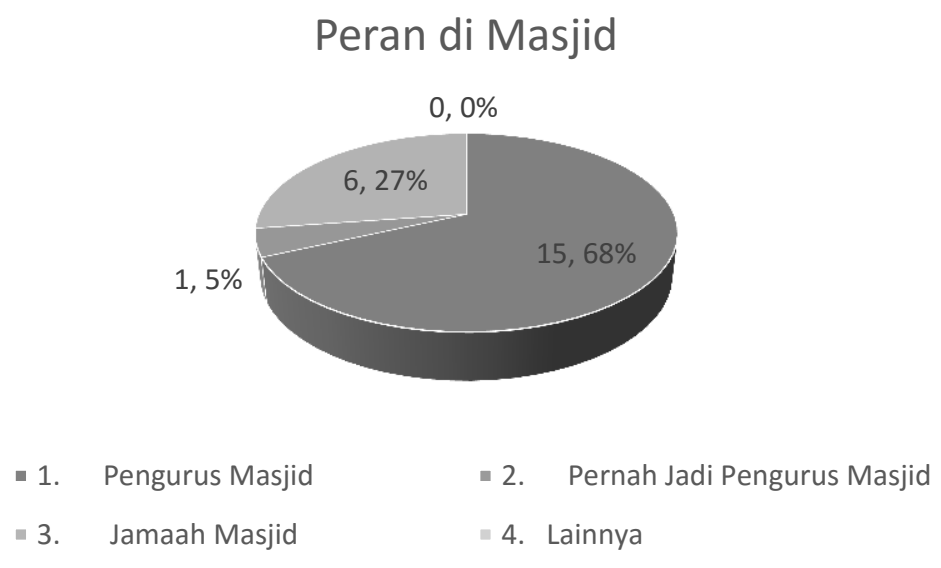

Gambar 6 Peserta berdasarkan Peranan di Masjid

Sumber : Kuesioner, data diolah

6. Sumber utama penerimaan Masjid, utama kegiatan masjid yang utama Peserta kegiatan berpendapat sumber dari infaq

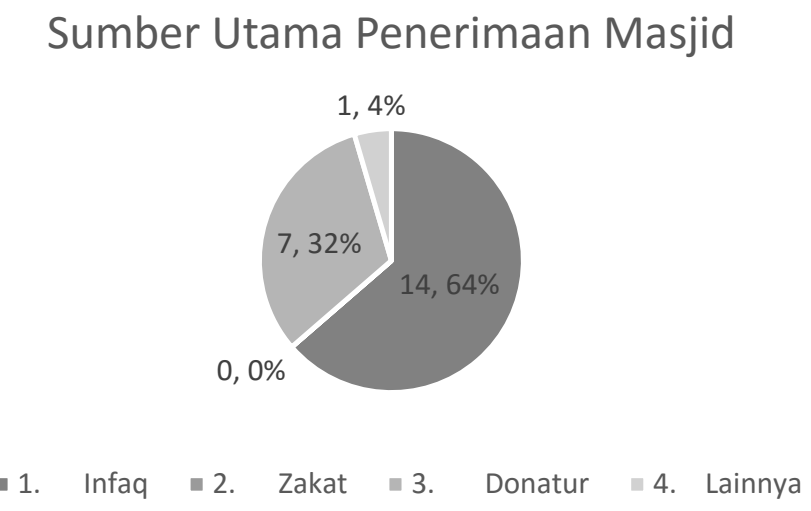

Gambar 7 Sumber utama Penerimaan Masjid

Sumber : Kuesioner, data diolah 


\section{Respon Peserta Terhadap kegiatan}

Hal yang menarik hampir dari semua peserta yang dominan pengurus Masjid masih mempunyai perspektif pengetahuan yang mendasar tentang wakaf dikaitkan dengan perkembangan wakaf terkini. Peserta sangat antusias bertanya dari hal yang sederhana sampai dengan hal yang sangat komplek. Berikut beberapa komentar peserta terkait kegiatan yang dilakukan : 1. Tema kegiatan, pada kegiatan ini temanya Wakaf uang untuk pengembangan operasional kegiatan Masjid, $18 \quad(82 \%)$ peserta menyatakan tema sangat menarik dan $4(18 \%)$ menyatakan menarik

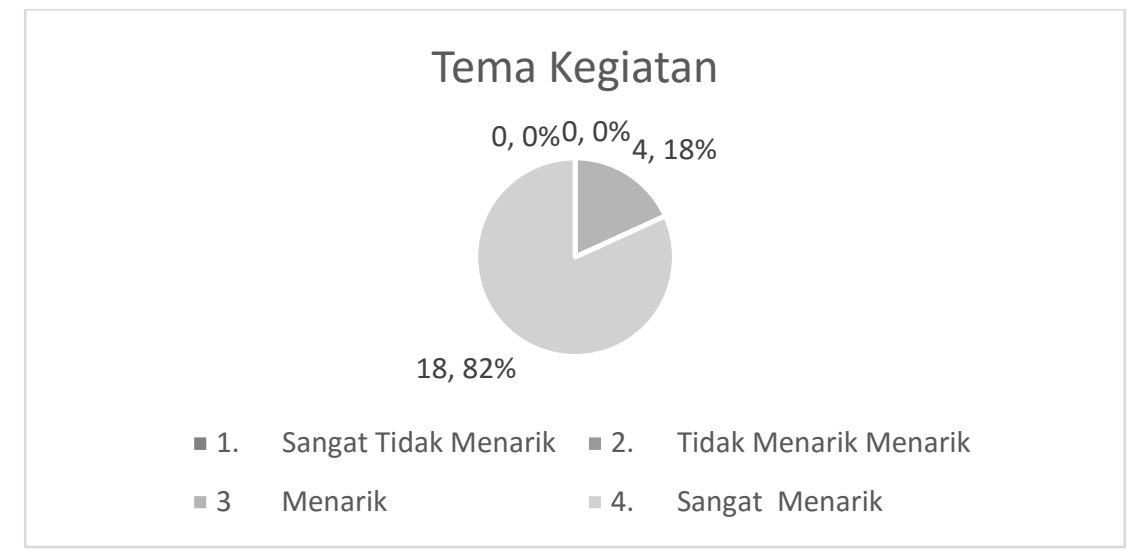

Gambar 8 Respon Terhadap Tema Kegiatan

Sumber : Kuesioner, data diolah

2. Materi yang disampaikan, $16(73 \%)$ menyatakan materi yang disampaikan sangat menarik, 5
(23\%) menyatakan menarik dan sisanya $1(5 \%)$ menyatakan sangat tidak menarik 


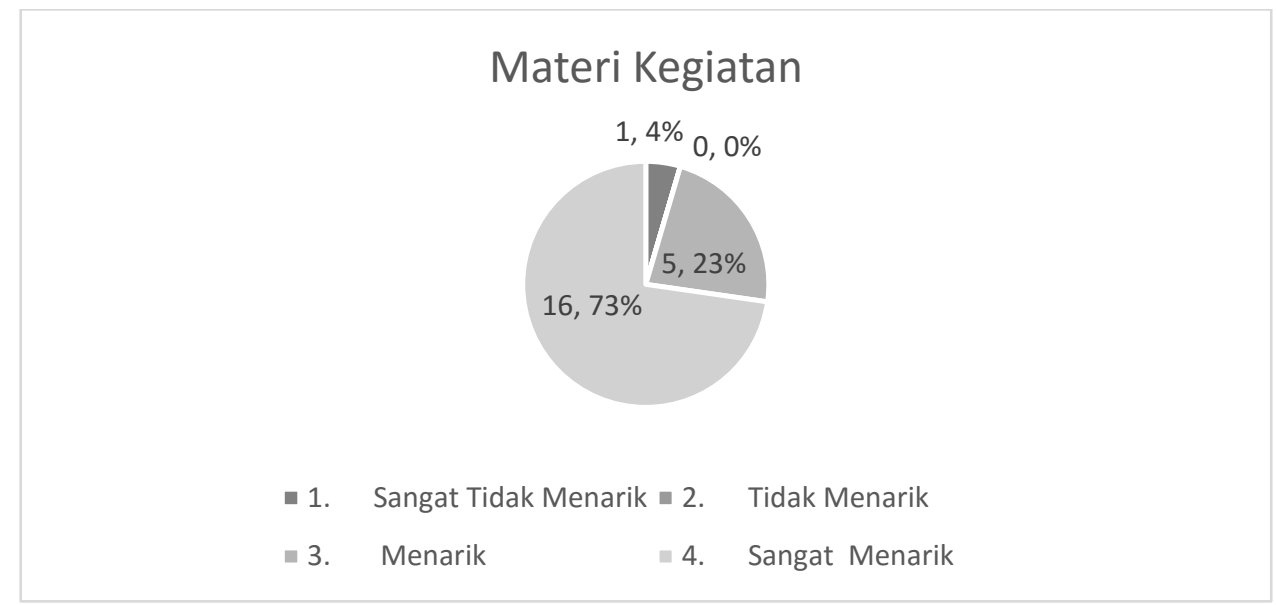

Gambar 9 Materi Yang disampaikan

Sumber : Kuesioner, data diolah

3. Pembicara/Trainer kegiatan, 15 menyatakan menarik dan $1(5 \%)$ (68\%) peserta menyatakan peserta menyatakan sangat tidak pembicara/ trainer sangat menarik menarik, $6(27 \%)$ peserta

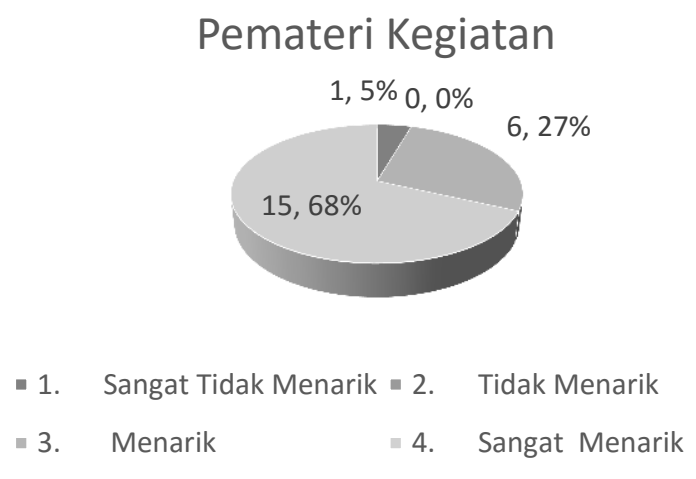

Gambar 10 Respon Terhadap Pembicara/Trainer

Sumber : Kuesioner, data diolah

4. Sarana dan Prasarana kegiatan, 16 (73\%) peserta menyatakan sarana dan prasarana yang digunakan dalam kegiatan ini sangat menarik dan sisanya $6(27 \%)$ menyatakan menarik 


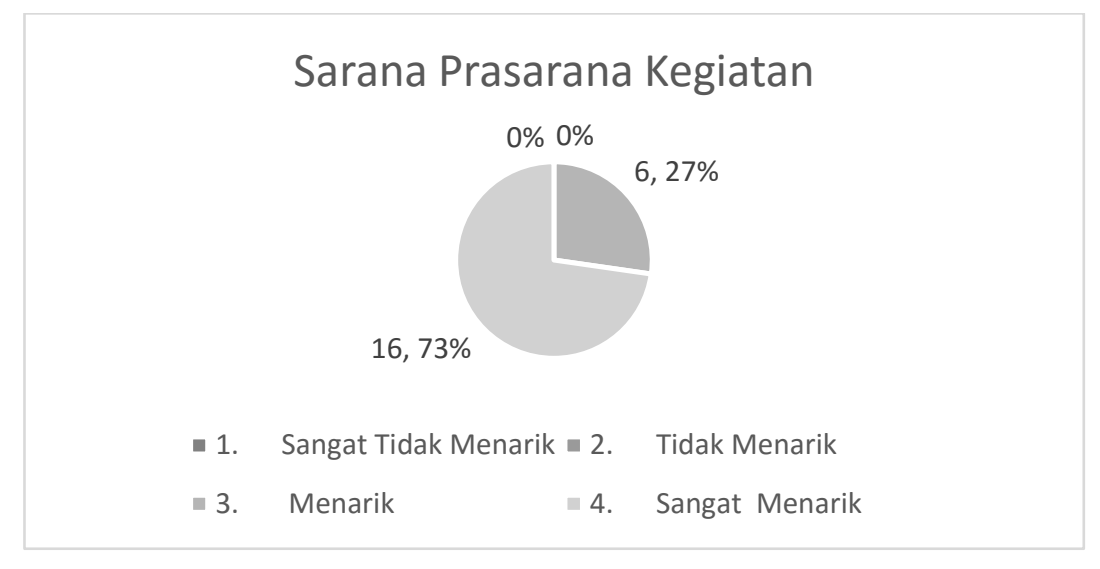

Gambar 11 Respon Terhadap sarana dan prasarana

Sumber : Kuesioner, data diolah

Kemampuan Pre dan Post test acara pelatihan berlangsung, hasil

\section{Peserta}

Ada sepuluh pertanyaan yang diajukan peserta sebelum dan sesudah jawaban pertanyaan yang benar sebagai berikut :

Tabel 1 Deskripsi Data Pre Dan Post Test Paired Samples Statistics

\begin{tabular}{lllrrr}
\hline & & Mean & N & $\begin{array}{c}\text { Std. } \\
\text { Deviation }\end{array}$ & $\begin{array}{c}\text { Std. Error } \\
\text { Mean }\end{array}$ \\
\hline \multirow{2}{*}{ Pair 1 } & Pretest & 64,5455 & 22 & 24,82842 & 5,29344 \\
& Posttest & 88,1818 & 22 & 12,58736 & 2,68363 \\
\hline
\end{tabular}

Sumber : Kuesioner, data diolah

Nilai yang diperoleh peserta diberikan soal yang sama maka sebelum pretest rata rata 64,5 (skala diperoleh rata-rata nilai 881,8 (skala 100) bahkan ada peserta hanya 100) dan nilai terendah 70 (sebanyak 1 mendapatkan skor 10 dan ada juga yang peserta) bahkan 8 peserta mendapatkan mendapatkan skor 100 (2 peserta). nilai 100 .

Setelah diberikan pelatihan dengan 
Tabel 2 Paired Samples Correlations

Paired Samples Correlations

\begin{tabular}{llccc}
\hline & N & $\begin{array}{c}\text { Correlatio } \\
\mathrm{n}\end{array}$ & Sig. \\
\hline Pair 1 & $\begin{array}{l}\text { Pretest \& } \\
\text { Posttest }\end{array}$ & 22 &, 515 &, 014 \\
\hline : Kuesioner, data diolah & & & &
\end{tabular}

Sumber : Kuesioner, data diolah

Berdasarkan tabel 2. terlihat nilai korelasi antara sebelum dan sesudah pelatihan sebesar $0,515(51,5 \%)$ yang menunjukkan korelasi sedang, tetapi pelatihan ini secara signifikan menambah pengetahuan peserta seperti terlihat pada tabel di bawah ini :

Tabel 3 Paired Sample Test

\begin{tabular}{|c|c|c|c|c|c|c|c|c|c|}
\hline \multicolumn{10}{|c|}{ Paired Samples Test } \\
\hline & & \multicolumn{5}{|c|}{ Paired Differences } & \multirow[t]{3}{*}{$\mathrm{T}$} & \multirow[t]{3}{*}{ df } & \multirow{3}{*}{$\begin{array}{l}\text { Sig. } \\
(2- \\
\text { tailed } \\
\quad)\end{array}$} \\
\hline & & \multirow[t]{2}{*}{ Mean } & \multirow[t]{2}{*}{$\begin{array}{l}\text { Std. } \\
\text { Deviatio } \\
n\end{array}$} & \multirow[t]{2}{*}{$\begin{array}{l}\text { Std. } \\
\text { Error } \\
\text { Mean }\end{array}$} & \multicolumn{2}{|c|}{$\begin{array}{l}95 \% \text { Confidence } \\
\text { Interval of the } \\
\text { Difference }\end{array}$} & & & \\
\hline & & & & & Lower & Upper & & & \\
\hline Pair 1 & $\begin{array}{l}\text { Pretest } \\
- \\
\text { Posttest }\end{array}$ & $\begin{array}{r}- \\
23,6363 \\
6\end{array}$ & $\begin{array}{r}21,2794 \\
2\end{array}$ & 4,53679 & $\begin{array}{r}- \\
33,0711 \\
3\end{array}$ & $\begin{array}{r}- \\
14,2016 \\
0\end{array}$ & $5,210^{-}$ & 21 &, 000 \\
\hline
\end{tabular}

Sumber : Kuesioner, data diolah

Berdasarkan nilai Sig 0,000 yang berarti < 0,05 maka pelatihan signifikan mempengaruhi pengetahuan peserta.

\section{FOTO KEGIATAN}

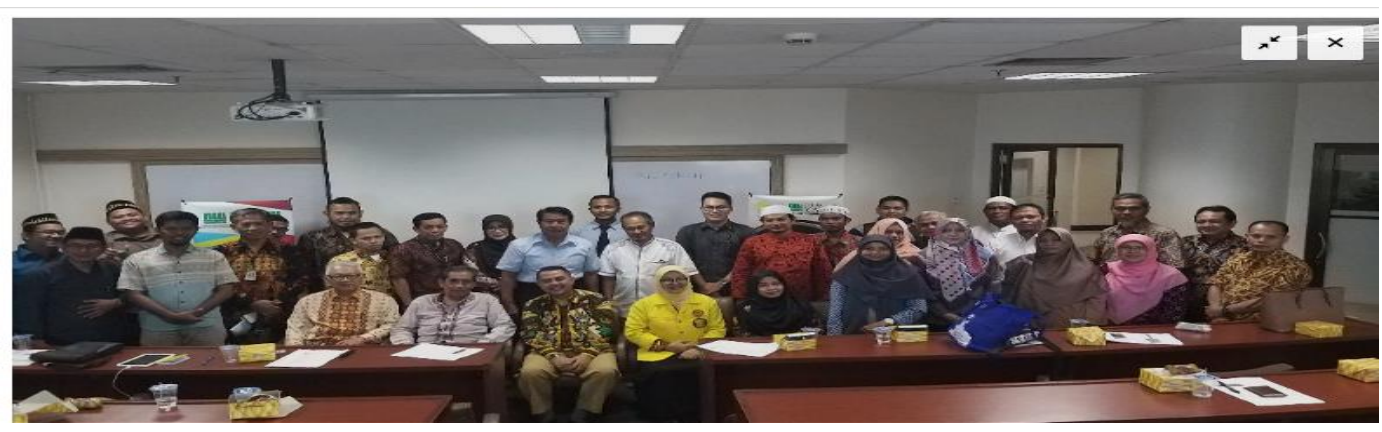

Gambar 12 Peserta Kegiatan 


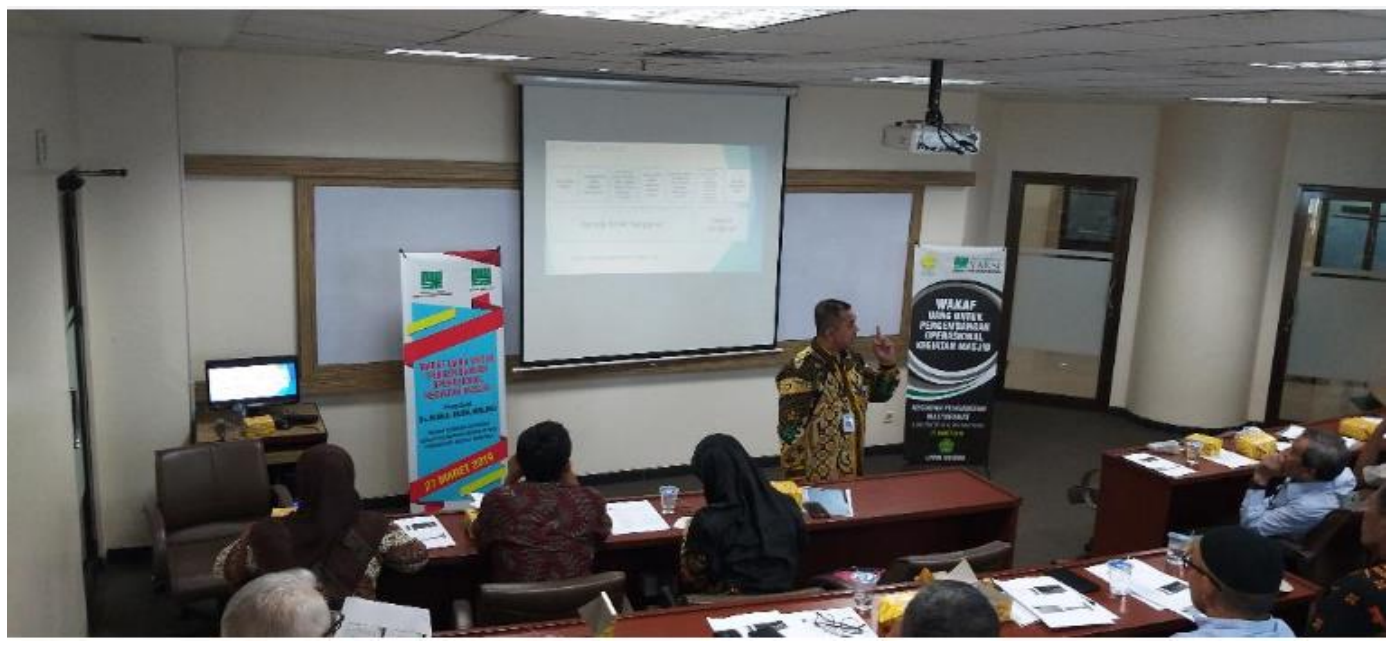

Gambar 13 Suasana Pelatihan

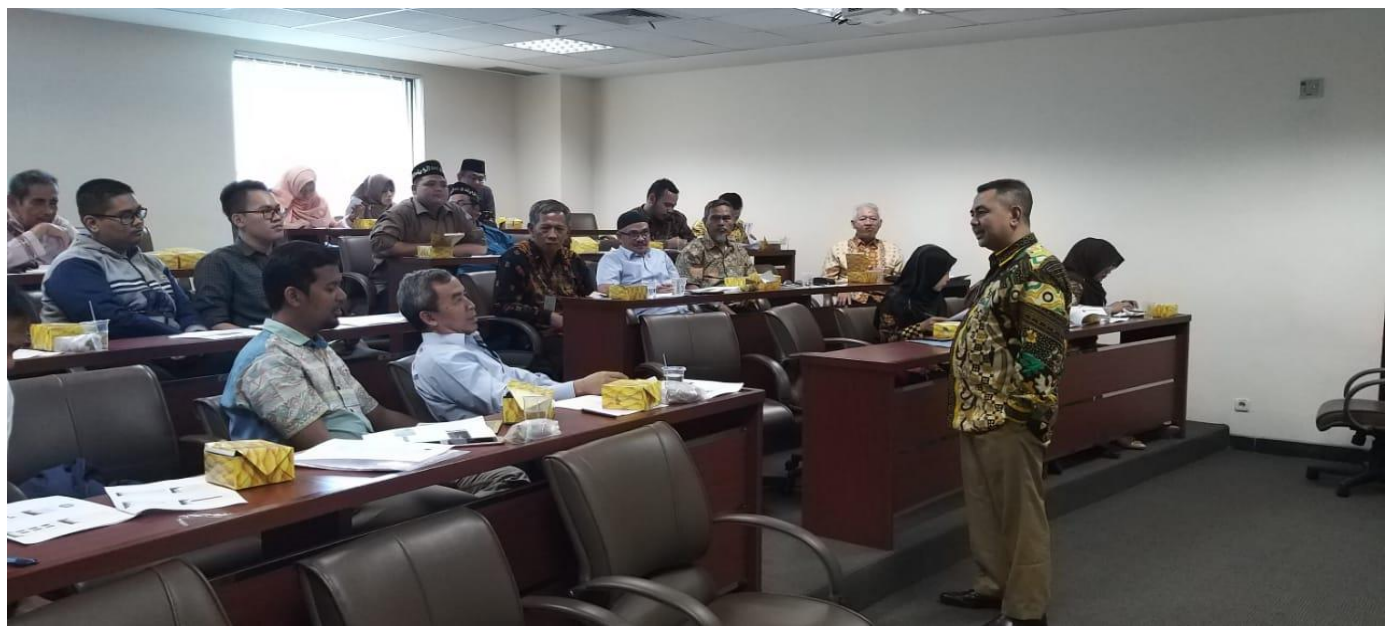

Gambar 14 Suasana Tanya Jawab

\section{KESIMPULAN}

Kegiatan P2M ini yang berupa kegiatan pelatihan dan pendampingan secar umum sudah berjalan sesuai yang direncanakan. Peserta sangat antusias mengikuti pelatihan dan ada 3 Pengurus Masjid akan menindaklanjuti kegiatan ini dengan melalkukan kegiatan pendalaman.

Hasil uji pre dan post test menunjukkan bahwa kegiatan pelatihan berpengaruh signifikan terhadap pengetahuan peserta tentang wakaf uang

\section{DAFTAR PUSTAKA}

Alqur'an dan Terjemahnya (1989), RIDepag, Semarang: Toha Putra,

Cizakca, Murat (2004). Ottoman Cash Waqfs Revisited: The Case Of Bursa 1555-1823, UK: FSTC

Dahlan, Rahmat (2014), Faktor-Faktor Yang Mempengaruhi Persepsi Nazhir Terhadap Wakaf Uang, Jurnal Al-Iqtishad: Vol. VI No. 2, Juli 2014. 

Kementerian Agama Republik Indonesia. (2013). Panduan Pengelolaan Wakaf Tunai. Direktorat Jenderal Bimbingan Masyarakat Islam, Direktur Pemberdayaan Wakaf

MUI-DSN (2006) , Himpunan Fatwa Dewan Syari'ah, Ciputat: CV. Gaung Persada Cet.ke-3,

Arif, Syafrudin. (2010). Wakaf Tunai sebagai Alternatif Mekanisme Redistribusi Keuangan Islam. Jurnal Ekonomi La Riba, Volume IV, No.1 Juli 2010 